\title{
Fracaso tricompartimental de suelo pélvico
}

\author{
García-Montes F, Vicens Vicens A, Ruiz Rosselló J, Ozonas Moragues M.
}

Unidad de Suelo Pélvico. Servicio de Urología. Hospital Universitario Son Dureta. Palma de Mallorca

Actas Urol Esp. 2008;32(10):1048

$\mathrm{P}_{\mathrm{n}}^{\mathrm{a}}$ aciente de 67 años de edad sin antecedentes médicos o medicamentosos de interés que consulta por sindrome miccional obstructivo con ocasional incontinencia urinaria de esfuerzo, incontinencia anal a gases y sólidos, metrorragia y sensación de bulto perineal de años de evolución habiendo empeorado en los últimos 6 meses. La Figura 1 muestra los hallazgos de la exploración vaginal en la que se apreció uretrocistocele grado IV, prolapso uterino grado IV con enterocele grado IV y prolapso rectal grado IV. La reducción manual del prolapso con la vejiga llena reprodujo la incontinencia urinaria y la incontinencia anal a gases. La resonancia magnética abdomino-pélvica demostró la existencia de un gran mioma uterino. Se consideró innecesaria la realización de otros estudios funcionales ante la clara indicación quirúrgica del caso. La Figura 2 muestra los resultados seis años tras la intervención, que consistió en laparotomía supraumbilical con: (1) Histerectomía y doble anexectomía; (2) reducción del enterocele y del prolapso rectal; (3) colposacropexia con malla retroperitoneal avanzada hasta el cuerpo perineal; (4) culdoplastia reforzada con epiplon mayor, (5) colposuspensión tipo Burch y (6) esfinteroplastia anal por vía perineal. La paciente permanece sin prolapsos pélvicos y con continencia urinaria y fecal.

Correspondencia autor: Dr. F. García-Montes

Unidad de Suelo Pélvico. Servicio de Urología

Hospital Universitario Son Dureta

Andrea Doria, 55 - 07014 Palma de Mallorca. Tel.: 971175000

E-mail autor: docvic24@hotmail.com

Información artículo: Imágenes en Urología

Trabajo recibido: junio 2007

Trabajo aceptado: julio 2007

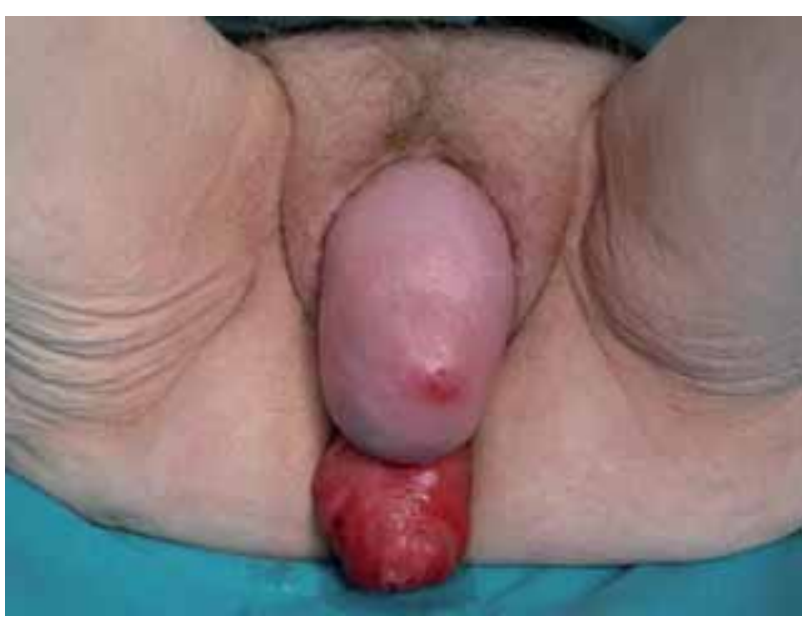

\section{FIGURA 1}

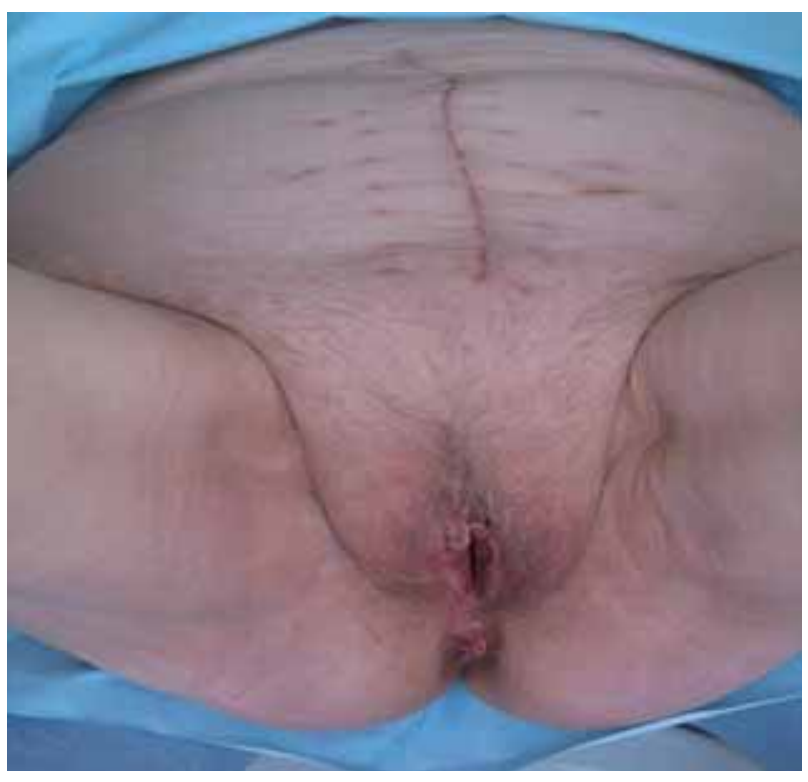

FIGURA 2 